\title{
Challenges in the implementation of character education in elementary school: experience from Indonesia
}

\author{
Winarni Jhon, Yogyakarta State University, Indonesia, winarnijhon.2019@student.uny.ac.id ORCID:0000- \\ 0003-2327-0575 \\ Sugito, Yogyakarta State University, Indonesia.Sugito@uny.ac.id \\ Enny Zubaidah, Yogyakarta State University, Indonesia. enny_zubaidah@uny.ac.id ORCID: 0000-0001- \\ 8256-3998 \\ Ali Mustadi, Yogyakarta State University, Indonesia, ali_mustadi@uny.ac.id ORCID: 0000-0002-7620- \\ 4582
}

\begin{abstract}
This article was aimed to identify the challenges that occur in the implementation of character education in elementary schools in Indonesia. This study applied a systematic review of literature using search protocol based on the PRISMA recommendation statement. The initial step of the study was the formulation of the research problem, then search of relevant research results from national journals on Garuda database and journal website. Then, an analysis of relevant research results was carried out in relation to the challenges in implementing the primary school character education program in Indonesia. The lack of support such as socialization, trainings, facilities and infrastructure were the main challenges that came from the government. Challenges from the teacher mostly focus on the difficulty and incompetence in assessing students' character. Challenges from the parents mostly related to the lack of support such as attention, participation and supervision for student character education.
\end{abstract}

Keywords: Character education, challenges, solutions, elementary school

Received: 18.11.2020 Accepted: 16.12.2020 $\quad$ Published: 22.01.2021

\section{INTRODUCTION}

The Ministry of Education and Culture of Indonesia has implemented curriculum 2013 as new curriculum. This government policy is conducted to fulfil the demands of the times that require curriculum renewal in order to produce better quality graduates. There is a significant difference between the curriculum 2006 and curriculum 2013 related to graduation competency standards, material, process and assessment. Changes in the learning process of learning and assessment are characterized by an emphasis on aspects of attitude. In other words, Indonesia's latest curriculum demands a balanced education between students' attitudes, knowledge and skills. Based on Presidential Regulation Number 87 in 2017 concerning strengthening of character education, there are 18 values of national character education namely religiosity, honesty, tolerance, discipline, hard work, creativity, independence, being democracy, curiosity, nationalism, patriotism, achievement appreciation, friendship, love of peace, environmental awareness, fondness of reading, social care, and responsibility.

Character education is a planned and systematic approach and aims to educate students to become good citizens who are shown with a responsible, honest and proud attitude (Çubukçu, 2012). Aside from being an approach, character education is also a process to increase student understanding (Almerico, 2014) and self-development in the form of moral development and good attitude (Pattarro, 2016). By having good character, students have a tendency to improve academic achievement (Nurhasanah \& Nida, 2016) and decrease negative behaviour (Dodds, 2016). Character education is carried out consciously in the form of repeated habituation to influence student behavior (Abu, Mokhtar, Hassan, \& Suhan, 2015). Education related to character development needs to be instilled early on in elementary school because it is a factor that determines the quality of students when they grow up (Ferdiawan \& Putra, 2013). Effective implementation of character education in elementary school will have a long term impact as student transition into higher education such as middle school years (Khoury, 2017). In addition, the age of elementary school students (6-12 years) is crucial age to build a solid foundation for the formation of student character (Rokhman, Hum, Syaifudin, \& Yuliati, 2014).

The positive impact of the implementation of character education in elementary school students in Indonesia is still not apparent even though the implementation of character education for elementary school students has been systematically regulated in Presidential Regulation Number 87 in 2017. Character education has become a major issue in Indonesia since 2012 (Istiningsih, 2016). The national 
character crisis is prevalent especially among the younger generation such as elementary school students (Abdi, 2018). News about cheating, bullying, littering, being late to school, skipping class, mocking classmates, doing violence done by elementary school students can still be found in various media and in everyday life. The Indonesian Child Protection Commission (KPAI) reported that there were around 153 cases of child abuse in schools. A total of 60 people from the total number were cases of bullying of elementary school students (Koagouw, 2019, December 31). The brawl case done by sharp weapons among elementary school students also had occurred in Sukabumi District. In fact, these students reportedly carried sharp weapons during brawls such as sickles, jagged iron plates and gears (Alamsyah, 2020, March 1)). In addition, based on a survey conducted by the Program for International Student Assessment (PISA), the competency score of Indonesian students at PISA was 371 in 2018, the same number since 2000 (Putra, 2020, April 7). This means that there has been no improvement over the past 20 years and poor management interest in reading Indonesian students and the low literacy skills of Indonesian students This shows that schools are still not maximally playing their support in instilling the character education of elementary school students in Indonesia.

There are various kinds of challenges in the implementation of character education in elementary schools in Indonesia both from internal and external factors (Zurqoni, Retnawati, Apino \& Anazifa, 2018). Internal barriers are related to policy and curriculum (Almerico, 2014). Meanwhile, external barriers are related to the social environment (Sultoni, 2016). Other challenges include the lack of programs and communication between parents and schools (Wibowo, 2014; Fahmi \& Susanto, 2018; Wijanarti, Degeng \& Untari, 2019), the complexity of student character assessment systems (Anwar, 2014; Latip, 2013; Siagian, 2015), lack of facilities and infrastructure, and the imbalance between the number of teachers and students (Morelent \& Syofiani, 2015; Salam, 2017). This shows that the challenges related to the implementation of character education in elementary schools in Indonesia come from the government, schools and parents.

Type of challenges in an elementary school with other elementary schools can show different results. It is influenced by the support of government, schools (teachers and principals) and parents as actors in the implementation of character education. The support of government is very much needed in relation to providing support in the form of socialization and training and supervision to elementary schools. The school, namely the teacher and the principal, also holds the responsibility and task in planning to carry out an assessment of the character of students, for example related to the planning of a character planting program that is suitable for elementary students and the preparation of character assessment indicators. The support of parents also plays a support in providing support in the form of attention, supervision and communication between parents and teachers related to the character of elementary school students. Temiz (2016) stated that the most important partners for the solution of character issues are teachers, managers, other staff and parents. Thus, it is important for the parents to create environment where students can learn and enforce the values on which good character is based (Chou, Yang, \& Huang, 2014).

Research related to character education mostly focuses on applying model e.g. (Anggraini \& Kusniarti, 2016), lesson plan model e.g. (Temiz, 2019), strategy e.g. (Fahmi \& Susanto, 2018; Mislia, Mahmud, \& Manda, 2016), and media e.g. (Turan \& Ulutas, 2016) to develop certain character for students. Meanwhile, other studies only discussed the support of the principal e.g. (Salam, 2017), and the support of teachers e.g. (Ülger, Yiğittir, \& Ercan, 2014; Malinda, Mwania \& Maithya, 2017) in implementing character education in elementary schools. For example, Salam (2017) result study showed principal had a support in implementing character education, namely establishing cooperation between school members, giving good examples, \& supervising. Additionally, some of the recent and most pronounced studies in character education have focused on the implementations e.g. (Anwar, 2014; Latip, 2013; Sujatmiko, Arifin, \& Sunandar, 2019; Siagian, 2015), impacts of character education in Indonesia e.g. (Fahmy, Bachtiar, Rahim, \& Malik, 2015), and the importance of certain character education e.g. (Pane \& Patriana, 2015).

Therefore, it is necessary to increase the study of literature that can provide an overview, information, guidance in carrying out effective character education in elementary schools in Indonesia. The purpose of this study is to identify the results of research from 2013-2020 related to challenges from the government, schools and parents in the implementation of character education in elementary schools in Indonesia. Author hopes that the results of the systematic revew in this study can provide benefits, especially for the government, school principals, teachers and other school members related to challenges and solutions to challenges related to the implementation of effective character education. This is the key to realizing the golden generation of Indonesia in 2045.

There are three research questions in this study. First question is what are the challenges from the governments in the implementation of character education in elementary school in Indonesia?'. 
Second is what are the challenges from the teachers in the implementation of character education in elementary school in Indonesia?'. Third is what are the challenges from the government in the implementation of character education in elementary school in Indonesia?'

\section{METHODS}

This study applied a systematic review of literature using search protocol based on the PRISMA (Preferred Reporting Items for Systematic Reviews and Meta-Analysis) recommendation statement (Moher, Liberati, Tetzlaff, \& Altman, 2009). A systematic review can be defined as a review of a clearly formulated question that uses systematic and explicit methods. The goal is to identify, select, and critically appraise relevant research, and also to collect and analyze data from the studies that are included in the review (Moher, Liberati, Tetzlaff, \& Altman, 2009).

\section{Literature Search Process}

Literature search process is done through the search on journal website. In order to ensure the quality of the article, we searched articles from journals which are accredited "Sinta 2" by the Ministry of Research Technology and Higher Education Republic of Indonesia. This search resulted in 75 articles about character education. However the research site mostly done in Elementary School in Java. Then, in order to ensure all relevant researches were identified including researches from other provinces in Indonesia such as Sumatra, Kalimantan, Sulawesi, and Bali, we also searched on Garuda database in May 2020. We typed keywords "character", "character education", "character implementation", "elementary school character education". Then, the results were refined by year from 2013 to 2020, which resulted in 624 articles. Therefore, the total article that we have gathered is 699 articles.

\section{Eligibility Criteria}

The eligibility criteria is done by applying inclusion criteria in order to select suitable studies and keep the review focused. The inclusion criteria were:

1. articles are published on national journals indexed in Sinta (ranging from grade 5 to grade 2). Sinta is an index system made by Ministry of Research, Technology and Higher Education. It is a platform to facilitate the collection of publications of researchers, institution and journals in Indonesia.

2. articles were published from 2013 to 2020 in order to obtain accurate and up-to-date information on the implementation of character education in Indonesia.

3. the research site was one of the 37 provinces in Indonesia as a representation of the implementation of elementary school character education in various regions of Indonesia such as the western, central and eastern parts of Indonesia.

articles should provide information about the challenges in implementing character education in an Elementary School in Indonesia. Thus, literature study articles were not included.

After selecting the articles based on the inclusion criteria, 178 articles remained. Authors then read through the full text of each article. As a result, challenges in the implementation of character education in elementary school in Indonesia were found in 16 articles. We only included challenges from the results and discussions, and disregarded challenges from the literature review of an article. Figure 1 below provide an overview of the search protocol based on the PRISMA statement. 


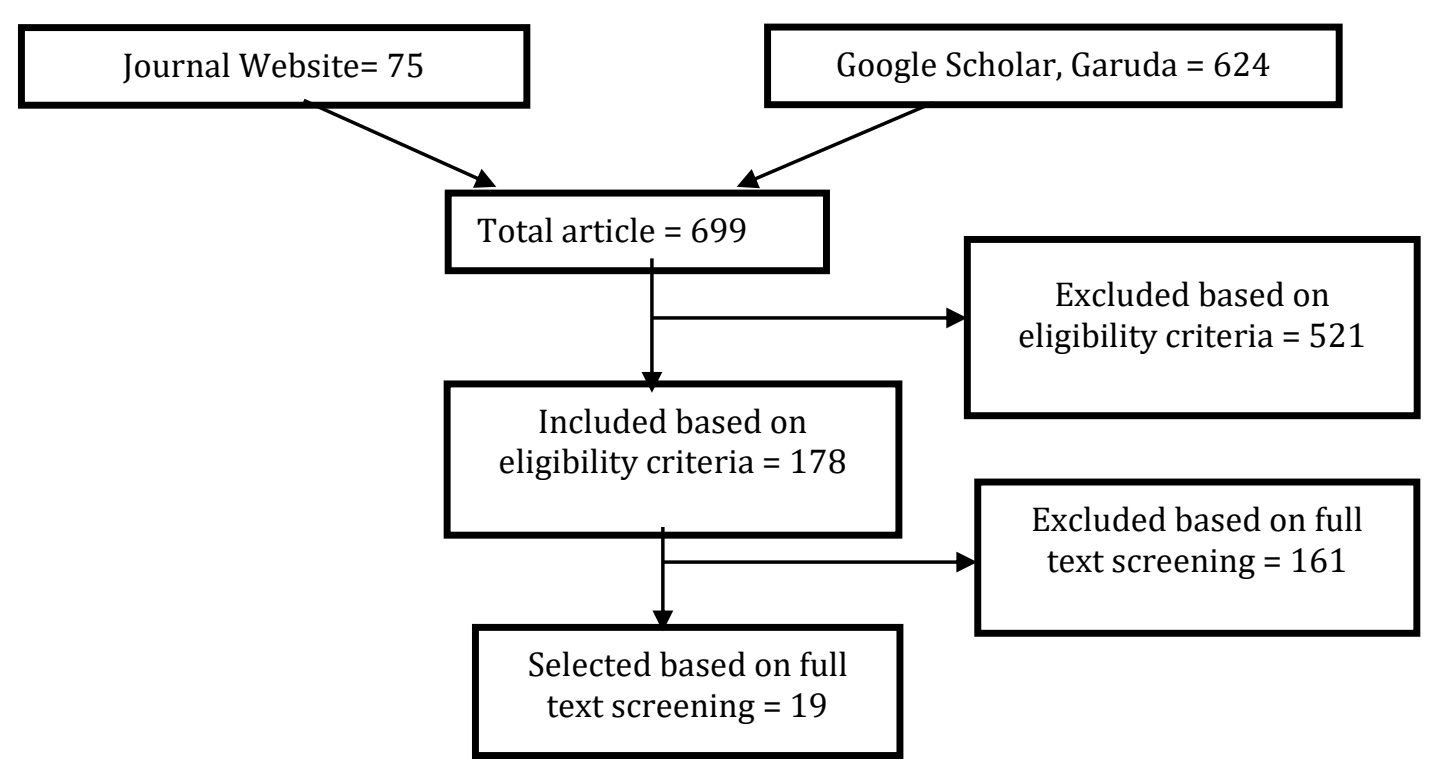

Figure 1. An overview of the search protocol based on the PRISMA statement.

\section{RESULTS}

This section answers the research questions of this study by discussing various kinds of challenges that occur related to the implementation of character education in elementary schools in Indonesia. Based on the results of the analysis of 19 relevant research results, the challenges are grouped into three categories, namely challenges from the government, schools and parents. The division is based on the source of the challenges or the actors who play a support in the successful implementation of elementary school student character education programs in Indonesia. Furthermore, researchers classify challenges based on categories that have been made. There are 2 challenges from the government, 3 challenges from the school (teachers \& school principal) and 2 challenges from the parents.

\section{What are the challenges from the government in the implementation of character education in elementary school in Indonesia?}

There are 2 types of challenges from the government, namely the lack of support, and challenges in planning, monitoring and evaluation. The first and main challenges were related to the lack of support in the form of training, funds, facilities and infrastructure. Darmayanti \& Wibowo's (2014) found that the government only provided socialization through teacher's working group. There was no direct training for the teachers in Public Elementary School in Yogyakarta. The socialization and training that has been provided by the Government so far are still lacking. The form of support most needed by schools is training and clear technical instructions about character education. The following table 1 shows the types of challenges from the government.

Table 1. Challenges from the government in the implementation of character education in elementary school in Indonesia

\begin{tabular}{|c|c|c|}
\hline $\begin{array}{c}\text { Types of } \\
\text { Challenges }\end{array}$ & Sub-categories & Articles \\
\hline $\begin{array}{l}\text { The lack of } \\
\text { Support }\end{array}$ & $\begin{array}{l}\text { Lack of socialization and training } \\
\text { Lack of funds for facilities, programs and its } \\
\text { poor management } \\
\text { Unavailability of learning sources } \\
\text { (guidebooks) }\end{array}$ & $\begin{array}{l}\text { (Darmayanti \& Wibowo, 2014) } \\
\text { (Darmayanti \& Wibowo, 2014), } \\
\text { (Wibowo, 2014), (Sujatmiko, Arifin \& } \\
\text { Sunandar, 2019), (Morelent \& Syofiani } \\
\text {,2015), (Yalida, 2019), [Hamzah, } \\
\text { 2016) } \\
\text { (Latip, 2013) }\end{array}$ \\
\hline
\end{tabular}




\begin{tabular}{|l|l|l|}
\hline $\begin{array}{l}\text { Challenges in } \\
\text { planning, } \\
\text { monitoring \& } \\
\text { evaluation }\end{array}$ & $\begin{array}{l}\text { Lack of monitoring and evaluation } \\
\text { Imbalance between the amount of school } \\
\text { supervisors with the number of schools each } \\
\text { district }\end{array}$ & $\begin{array}{l}\text { (Darmayanti \& Wibowo, 2014) } \\
\text { (Darmayanti \& Wibowo, 2014) }\end{array}$ \\
\hline
\end{tabular}

The government tended to focus on primary schools in urban areas. As a result, there was a lack of access to information and learning resources about the implementation of character education especially for elementary schools located in rural areas (Latip, 2013). However, the most common problem was the lack of funds for school facilities and infrastructure to support the implementation of character education. It happened not only in Public Elementary Schools, (Darmayanti \& Wibowo, 2014; Morelent \& Syofiani, 2015) but also Private Elementary Schools (Wibowo, 2014; Sujatmiko, Arifin \& Sunandar, 2019). For example, Islamic School of Yogyakarta had difficulty implementing religious education through outbound activities because there were no supporting facilities. This showed that the implementation of a character development program can be disrupted due to lack of supporting facilities and infrastructure. In order to implement character education, schools conducted many activities (Zurqoni, Retnawati, Apino \& Anazifa, 2018). These activities needed a lot of expense. To anticipate the costs of the activities, the school obtained funding from its school committee, the government, and alumni donations. This problem became evident and often happened in State Elementary Schools due to overwhelming amount of students. Students had difficulty to use them simultaneously (Morelent \& Syofiani, 2015). Teacher creativity also decreased because of inadequate facilities and infrastructure. It caused the lack of variety of character education program development for elementary school students (Morelent \& Syofiani, 2015).

Second challenges were related to the planning, monitoring and evaluation of the implementation of character education conducted by the government. Monitoring of the implementation of character education was still lacking because of the difficulty in reaching schools that are scattered in several places. In addition, there were not enough school supervisors (Darmayanti \& Wibowo, 2014). Evaluations conducted by the Department of Education were also not optimal because they did not assess the implementation of character education in schools and only focused on the completeness of documents (Darmayanti \& Wibowo, 2014). In fact, monitoring and evaluation activities are very important in order to see the shortcomings and achievements of character education goals in each school. This information can be useful as an illustration to make improvements to the challenges that occur.

Ideally, the facilities and infrastructure available at schools should be complete such as a place for worship, a place for finding lost items, vision and school rules, absenteeism, posters and slogans, communication and information media, reading rooms, and equipment cleaning tools such as bins. Lack of facilities and infrastructure in schools can cause the implementation of character education to be hampered. Solutions that can be done include installing aphorisms, slogans, verses of the Qur'an, hadith, and students' works (Siagian, 2015), improving the system of facilities \& infrastructure management as well as promoting optimal use and maintenance involving all parties (Darmayanti \& Wibowo, 2014).

The lack of socialization from the government was also the main problem which needs to be solved. According to Budiarta, Artini, Seken, and Santosa (2018), government needed to conduct more intensive trainings and workshops on character education. The topic of the workshop and training should include innovative learning models, methods and learning media in the implementation of character education. In addition, other support in the form of financial support is also needed in order to be able to run the program optimally. The government can also implement a school of best practices or character education pilot schools and support discussion activities between teachers to share experiences.

\section{What are the challenges from the school (principals and teachers) in the implementation of character education in elementary school in Indonesia?}

The influential actor to gain excellence in school education is not only the principal but also all individuals including teachers (Grissom, Kalogrides \& Loeb, 2015). Teacher is fundamental in achieving the desired individual characteristics (Sahin, 2019). Related to the implementation of character education in elementary school, teachers has an important support. One of them is to be able to design elaborative and explorative activities in the preparation of the lesson plan and learning process (Marini, 2017). However, the change of various policies caused school principals and teachers to become confused, and overwhelmed. This is due to the fact that teachers are more closely connected to student learning with front line contacts than principals (Pang \& Miao, 2017). There are 3 types of challenges from the school, namely challenges in the planning, implementation and assessment.

First challenges were related to program planning. According to Sadia, Arnyana \& Muderawan (2013), only 28.79\% of Primary School teachers in Bali province had participated in seminars, training or 
workshops both offline and online. This showed that most elementary school teachers in the province of Bali had never attended training related to the implementation of character education. This caused teachers to be confused because they did not have clear understanding about the theory and practice on how to implement character education in schools (Nitte \& Bulu, 2020). Socialization or training is really important because it is the way for teachers to get information, share information and discuss issues related to character education. The lack of understanding also caused its application not carried out optimally. There were several other problems that occured. First, teacher's inability to select suitable model, method \& learning media (Latip, 2013; Sadia, Arnyana \& Muderawan, 2013; Parida, Sirhi \& Dike, 2019; Wijanarti, Degeng \& Untari, 2019; Latip, 2013 2013). Second, teacher's inability to integrate character education into learning programs (Latip, 2013; Sadia, Arnyana \& Muderawan, 2013). Third, planning activities that did not involve many parties (Suprio, Hanurawan \& Sutarno, 2020). Fourth, random and unclear formulation of character values (Darmayanti \& Wibowo, 2014).

The second challenges were related to program implementation. One of the problems was the difficulty in inculcating character values through support models (Latip, 2013). Ideally, teacher's behaviour and words must be able to show good character in school in order to encourage students to imitate them and create awareness in students. However, school principals, teachers and staff had not been able to set good examples for their students (Nitte \& Bulu, 2020). This was indicated by the behaviour and speech of teachers and principals that still did not reflect politeness, friendliness, and neatness values. While in the learning process, the implementation of character education was not yet apparent because the teacher was still focused on how to make students understand the learning material well (Darmayanti \& Wibowo, 2014). Learning activities mostly focused on concepts and not direct practice. For example, in learning material about environment, learning activities focused on discussion of the definition, types and importance of the environment. As a result, students had a good understanding of the environment, but they were not able to show positive character of caring for the environment. In addition, teachers were also lacking in supervising students (Sujatmiko, Arifin \& Sunandar, 2019). It was proven by character assessment activities that were not routinely carried out (Suprio, Hanurawan \& Sutarno, 2020). This was caused by the large number of students, especially student at the Public Elementary School. As a result, teachers become overwhelmed and not active in supervising character education (Morelent \& Syofiani, 2015; Salam, 2017). Table 2 below shows the 3 types of challenges from teachers and principals.

Table 2. Challenges from the school (principals and teachers) in the implementation of character education in elementary school in Indonesia.

\begin{tabular}{|c|c|c|}
\hline Type of challenges & Sub-categories & Articles \\
\hline $\begin{array}{l}\text { Challenges in the } \\
\text { Planning }\end{array}$ & $\begin{array}{l}\text { Difficulty to select suitable model, } \\
\text { method, media } \\
\text { Difficulty to integrate character into } \\
\text { each lesson } \\
\text { The teaching method is not variative } \\
\text { Difficulty to design lesson plan and } \\
\text { make instrument of assessment } \\
\text { The planning activities do not involve } \\
\text { other parties } \\
\text { Teachers seldom participate in training } \\
\text { and socialization } \\
\text { Disagreement between teachers and } \\
\text { principal }\end{array}$ & $\begin{array}{l}\text { (Latip , 2013), (Sadia, Arnyana \& } \\
\text { Muderawan, 2013), (Parida, Sirhi \& } \\
\text { Dike, 2019), (Wijanarti, Degeng \& } \\
\text { Untari, 2019), (Latip , 2013) } \\
\text { (Latip , 2013), (Sadia, Arnyana \& } \\
\text { Muderawan, 2013) } \\
\text { (Wijanarti, Degeng \& Untari, 2019) } \\
\text { (Nitte \& Bulu, 2020), (Darmayanti } \\
\text { \& Wibowo, 2014) } \\
\text { (Suprio, Hanurawan \& Sutarno, } \\
\text { 2020) } \\
\text { (Sadia, Arnyana \& Muderawan, } \\
\text { 2013) } \\
\text { (Nitte \& Bulu, 2020) }\end{array}$ \\
\hline $\begin{array}{l}\text { Challenges in the } \\
\text { Implementation }\end{array}$ & $\begin{array}{l}\text { Difficulty and incapability to be a model } \\
\text { Difficulty to monitor and the lack of } \\
\text { monitoring from the teacher } \\
\text { Inconsistency to integrate character } \\
\text { value in the learning process } \\
\text { The lack of habituation } \\
\text { The lack of religious learning } \\
\text { The mismatch between character value } \\
\text { and vision and mission of the school } \\
\text { The lack of knowledge about the }\end{array}$ & $\begin{array}{l}\text { (Latip , 2013), (Nitte \& Bulu, 2020), } \\
\text { (Yalida, 2019) } \\
\text { (Latip, 2013), (Sujatmiko, Arifin \& } \\
\text { Sunandar, 2019) } \\
\text { (Darmayanti \& Wibowo, 2014) } \\
\text { (Suprio, Hanurawan \& Sutarno, } \\
\text { 2020) } \\
\text { (Fahmi \& Susanto, 2018) } \\
\text { (Nitte \& Bulu, 2020) } \\
\text { (Darmayanti \& Wibowo, 2014), }\end{array}$ \\
\hline
\end{tabular}




\begin{tabular}{|c|c|c|}
\hline & $\begin{array}{l}\text { implementation of character education } \\
\text { Lack of commitment and hesitance from } \\
\text { teachers }\end{array}$ & $\begin{array}{l}\text { (Nitte \& Bulu, 2020) } \\
\text { (Hidayati, Tohiroh \& Istyarini, } \\
\text { 2017) }\end{array}$ \\
\hline $\begin{array}{l}\text { Challenges in the } \\
\text { Assessment }\end{array}$ & $\begin{array}{l}\text { Difficulty to formulate indicator of } \\
\text { character value } \\
\text { The mismatch between learning } \\
\text { material and character value } \\
\text { Difficulty to identify the character value } \\
\text { Difficulty to select suitable assessment } \\
\text { The lack of attention on character } \\
\text { assessment and documentation } \\
\text { The lack of time } \\
\text { The lack of technological competency } \\
\text { Inconsistency of character assessment } \\
\text { The overwhelming number of students }\end{array}$ & $\begin{array}{l}\text { (Anwar, 2014), (Latip, 2013), } \\
\text { (Siagian, 2015), (Wijanarti, Degeng } \\
\text { \& Untari, 2019) } \\
\text { (Anwar, 2014), (Siagian ,2015) } \\
\text { (Anwar, 2014) } \\
\text { (Sadia, Arnyana \& Muderawan, } \\
\text { 2013), (Darmansyah, 2014) } \\
\text { (Sadia, Arnyana \& Muderawan, } \\
\text { 2013), (Narut \& Nardi, 2019), } \\
\text { (Darmayanti \& Wibowo, 2014) } \\
\text {, (Wijanarti, Degeng \& Untari, } \\
\text { 2019) } \\
\text { (Wijanarti, Degeng \& Untari, 2019) } \\
\text { (Nitte \& Bulu, 2020) } \\
\text { (Morelent \& Syofiani ,2015), } \\
\text { (Salam, 2017) }\end{array}$ \\
\hline
\end{tabular}

Character building in elementary school students in Indonesia is carried out in three ways namely habituation, exemplary from teachers, and discipline. The application of the three methods was quite good but not optimal. For example, activities to instill discipline in students are conducted through academic regulations; class rules; warning; and advice. However, discipline activities carried out by some teachers hinder other aspects of character. One of them is the students' critical thinking skills (Nastiti, 2015). Critical thinking skills are really needed in the $21^{\text {st }}$ century (Greenstein, 2012). Ideally, students should be able to ask, argue, conduct research, make conclusion from their observation activities, criticize, make decision, express themselves and think creatively, critically and scientifically (Aktamis \& Yenice, 2010). However, students were still afraid to ask questions and express their opinions (Nastiti, 2015). The reason was because students felt uncomfortable with the way some teachers teach. Teachers still used teacher-centered approach. Consequently, students were being passive, and afraid especially during learning activities in the classroom. This could hinder the formation of critical thinking skills on students.

The third challenges were related to assessment on students' character. According to Anwar (2014), there were no detailed instruments used by teachers to observe students' characters. The assessments were mostly done spontaneously. Teacher stated that they had difficulty in formulating character assessment indicators (Latip, 2013; Siagian, 2015; Wijanarti, Degeng \& Untari, 2019), difficulties in identifying character values (Anwar, 2014), and difficulties in choosing the assessment model (Sadia, Arnyana \& Muderawan, 2013; Darmansyah, 2014). Teacher only copied the assessment instruments in the teacher's book without first critical analysis on them. Teachers stated that they had a lack of understanding (Anwar, 2014; Siagian, 2015). In addition, the teacher also did not focus attitude assessment. Teacher still focused on cognitive aspects. As a result, when an evaluation was carried out by the supervisor regarding lesson plan, teachers could not show their lesson plans (Sadia, Arnyana \& Muderawan, 2013; Narut \& Nardi, 2019; Darmayanti \& Wibowo, 2014). Another problem was the lack of time to observe all students and complexity of assessments that must be done by the teacher (Wijanarti, Degeng \& Untari, 2019). For example, teachers should make character assessment rubrics in the form of observation assessment instruments (observation sheets) and attitude scale assessment instruments. Teachers should also assess affective, cognitive and skill aspects. On the basis of the above problems, the government had designed an online report card or e-report card in Elementary Schools to improve integrity, accountability and easiness for teachers to do assessment.

Teachers should have good understanding about innovative learning models that contribute to student character development. Previous research results showed that some learning models used to develop character values such as Problem Based Learning model (Jailani, Sugiman, \& Apino, 2017), Creative Problem Solving (Apino \& Retnawati, 2017), Higher Oder Thinking Skills (Retnawati, Djidu, Kartianom, Apino, \& Anazifa, 2018), Meaningful Learning (Latip, 2013), and Nature Environment Exploration model (Narut \& Nardi's, 2019). According to Darmayanti \& Wibowo (2014), there were 2 strategies related to the implementation of character education in elementary schools. First strategy was integration of character values into the learning process. The teacher should apply active and fun learning methods and habituation in the form of reinforcement to students. Second strategy was the 
implementation of school culture. School culture consisted of routine activities, spontaneous activities, support modelling, and conditioning. Ideally, there should be a meeting held by school principals and teachers in each new school year related to discussions about character values developed, the types of planting activities that need to be carried out and the problems that teachers might face in implementing character education. This is important to prevent problems such as lack of understanding, disputes between teachers and employees and mismatch of character values that are applied to the vision and mission of the school (Nitte \& Bulu, 2020).

\section{What are the challenges from the parents in the implementation of character education in elementary school in Indonesia?}

Parents' participation influence students' success such as academic achievement in school (Wei, Wu, Lv, Zhou, Han, Liu, \& Luo, 2016)and students' educational engagement (Erdener, 2016). However, diverse educational backgrounds, social, economic families can cause different intensity of support and impact on students (An, Wang, Yang, \& Du, 2018). There are parents who are very concerned about their children's education at school and at home. However, there are still many parents who do not pay attention on their children education. Table 3 below shows the challenges that come from the parents related to the implementation of character education in Indonesia.

Table 3. Challenges from the parents in the implementation of character education in elementary school in Indonesia

\begin{tabular}{|l|l|l|}
\hline \multicolumn{1}{|c|}{$\begin{array}{c}\text { Type of } \\
\text { challenges }\end{array}$} & \multicolumn{1}{c|}{ Sub-categories } & \multicolumn{1}{c|}{ Articles } \\
\hline $\begin{array}{l}\text { The lack of } \\
\text { parents' } \\
\text { support }\end{array}$ & $\begin{array}{l}\text { The lack of attention of and participation } \\
\text { The lack of collaboration between parents }\end{array}$ & (Wibowo, 2014), (Fahmi \& Susanto, \\
& $\begin{array}{l}\text { 2018), (Wijanarti, Degeng \& Untari, } \\
\text { The bad influence from television }\end{array}$ & 2019), (Sujatmiko, Arifin \& Sunandar, \\
& $\begin{array}{l}\text { 2019), (Salam, 2017), (Yalida, 2019) } \\
\text { The bad influence from the play }\end{array}$ & (Fahmi \& Susanto, 2018), (Darmayanti \\
& environment & \&ibowo, 2014), [Hamzah, 2016] \\
& & (Fahmi \& Susanto, 2018) \\
& & (Fahmi \& Susanto, 2018) \\
\hline $\begin{array}{l}\text { Challenges inn } \\
\text { finance }\end{array}$ & Incapability to cover all of programs & \\
\hline
\end{tabular}

There were 2 types of obstacles on the part of parents, namely the lack of parents' support and financial challenge. First challenges were related to the support of parents. Challenges related to the support of parents were the lack of parental supports in providing attention, active participation, guidance and supervision to children at home. According to Fahmi \& Susanto (2018), there was an imbalance between school and home education. Parents did not actively support character education to children. As a result, it caused the difficulty of changing the character of children. This problem was exacerbated by a bad social environment such as the influence of bad shows on TV (Darmayanti \& Wibowo, 2014). There was also bad influence from playing environment coming from peer groups, religious activities and even their own siblings (Fahmi \& Susanto, 2018) due to lack of monitoring by parents at home (Fahmi \& Susanto, 2018). Therefore, parents need much help from schools and teachers who can promote media literacy and related metacognitive skills. Another problem was the lack of good partnerships between parents and teachers (Wibowo, 2014; Fahmi \& Susanto, 2018; Wijanarti, Degeng \& Untari, 2019; Sujatmiko, Arifin \& Sunandar, 2019; Salam, 2017). Most parents did not know the purpose of character education to be achieved by the school and the development or character problems that their children had. Parents still assumed that school was daycare for children. This was due to the difference in expectation and perception of parents' obligations for students' education (Yulianti, Denessen, \& Droop, 2019). Parents' demographics such as educational background, financial status, and marital status may be influential on parents' involvement to support students' learning (Erdener, \& Knoeppel, 2018).

The second challenge was related to the lack financial ability of parents. According to Wibowo (2014), there was an assumption that the cost of education to attend SDIT in Yogyakarta for some parents is quite expensive. It was around from 300,000 until 600,000 rupiah. However, these costs did not include extracurricular activities and other activities that could support the implementation of character education in school. As a result, there were still some parents who asked for discount. Due to the economic problem faced by parents, it is less likely for them to provide expert monitoring of children's access to media (TV, radio, internet, computer games, books and magazines). 
Effective approaches for achieving student success are those that focus on parental participation (Flores, Morgan, Rivera, \& Clark, 2019). Parental participation includes education belief, academic expectation and implementing ways to support students' education (Toren, 2013). Related to the implementation of character education in elementary schools, cooperation between school-family-society is a very crucial component of character education. If the pattern of character education in the family is already well established, it will be easier for the students to receive character education in schools (Saidek, Islami, \& Abdoludin, 2016). Solutions related to the lack of the support of parents can be done by increasing activities involving parents through active communication, prayer books and homework (Siagian, 2015). Other activities also include reading with children and attending the planned character education program (Demirel, Özmat, \& Elgün, 2016; Castro et al., 2015). In order to achieve that, principal should also increase their instructional supervision and encourage teachers to communicate with parents. Therefore, parents can get a detailed description of the character education program and increase their motivation to support students' education.

\section{DISCUSSION AND CONCLUSIONS}

Type of challenges in an elementary school with other elementary schools can show different results because it is influenced by the support of government, schools (teachers/ principals) and parents as actors implementing character education. This study discussed the challenges based on the source of the problem or the actors who hold responsibility. There were challenges from the government, schools and parents, as it is stated by (Temiz, 2016) that the most important partners for the solution of character issues are teachers, managers, other staff and parents. Figure 2 below showed the taxonomy of challenges in the implementation of character education in elementary school in Indonesia.

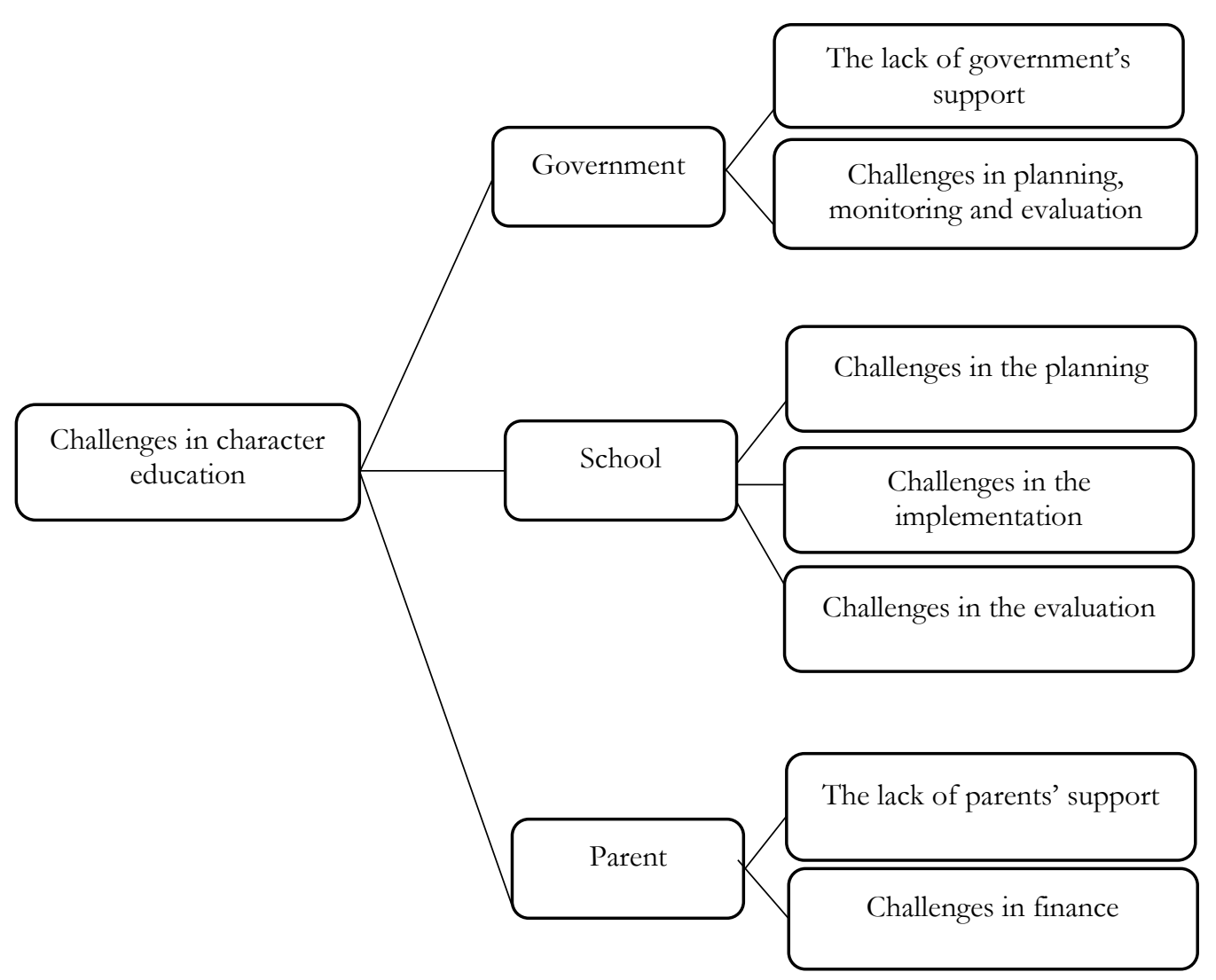

Figure 2. Taxonomy of challenges in the implementation of character

\section{education in elementary school in Indonesia.}

First, our study found that the lack of support such as socialization, trainings, facilities and infrastructure were the main challenges that came from the government. Available facilities and infrastructure were not enough compared to the amount of student. Students had difficulty to use them 
simultaneously (Morelent \& Syofiani, 2015). According to Budiarta, Artini, Seken, and Santosa (2018), government also needed to conduct more intensive trainings and workshops on character education. The topic of the workshop and training should include innovative learning models, methods and learning media in the implementation of character education.

Second, our review found that challenges from the teacher mostly focus on the difficulty and incompetence in assessing students' character. According to Anwar (2014), there were no detailed instruments used by teachers to observe students' characters. The assessments were mostly done spontaneously. Teacher stated that they had difficulty in formulating character assessment indicators (Latip, 2013; Siagian, 2015; Wijanarti, Degeng \& Untari, 2019), difficulties in identifying character values (Anwar, 2014), and difficulties in choosing the assessment model (Sadia, Arnyana \& Muderawan, 2013; Darmansyah, 2014). Ideally, there should be a meeting held by school principals and teachers in each new school year related to discussions about character values developed, the types of planting activities that need to be carried out and the problems that teachers might face in implementing character education. It is also important for the teachers to actively participate in socialization and training conducted by the government.

Third, our study discovered that challenges from the parents mostly related to the lack of support such as attention, participation and supervision for student character education. According to Fahmi \& Susanto (2018), there was an imbalance between school and home education. Parents did not actively support character education to children. As a result, it caused the difficulty of changing the character of children. Solutions related to the lack of the support of parents can be done by increasing activities involving parents through active communication, prayer books and homework (Siagian, 2015). Other activities also include reading with children and attending the planned character education program (Demirel, Özmat, \& Elgün, 2016; Castro et al., 2015).

Fourth, our review found that challenges from government, schools and parents are not mutually exclusive, they cross boundaries. For example, difficulty faced by teachers on how to assess character is related to the lack of socialization from the government. Similarly, support from the parents depends on collaboration and communication between schools and parents. There should be a meeting held by school principals and teachers in each new school year related to discussions about character values developed, the types of planting activities that need to be carried out and the problems that teachers might face in implementing character education.

This article identifies the current challenges from the government, schools (principals and teachers), and parents in the implementation of character education in elementary school in Indonesia. We examined 699 relevant researches about challenges in the implementation character education in elementary school conducted in different provinces in Indonesia. Then, we divided the challenges based on the source of the problem or the actors who hold responsibility. There were challenges from the government, challenges from schools and challenges from parents. Even though we have tried to include as many researches as possible from different provinces in Indonesia, it is very difficult to identify all the challenges due to the vast area of Indonesia and the complex nature of human behavior. In addition, this review only focused on elementary school level. Therefore, we propose future research recommendation about evaluation of character education in elementary school, middle school, and high school in Indonesia.

\section{REFERENCES}

Abu, L., Mokhtar, M., Hassan, Z., \& Suhan, S. Z. D. (2015). How to develop character of madrassa students in Indonesia. Journal of Education and Learning, 9(1), 79-86.

Abdi, M. I. (2018). The Implementation of Character Education in Kalimantan, Indonesia: Multi Site Studies. Dinamika ilmu, 18(2), 305-321.

Aktamis, H. \& Yenice, N. (2010). Determine of The Science Process Skills and Critical Thinking Skill Levels. Procedia Social and Behavioral Science 2, 3282-3288.

Alamsyah, S. (2020, March 1). Aksi Nekat Bocah SD Bawa Celurit Saat Tawuran Berujung Pembinaan. Detiknews. Retrieved from https://news.detik.com/berita-jawa-barat/d-4920405/aksi-nekatbocah-sd-bawa-celurit-saat-tawuran-berujung-pembinaan.

Almerico, G. M. (2014). Building character through literacy with children's literature. Research in Higher Education Journal, 26(1), 1-13.

An, G., Wang, J., Yang, Y., \& Du, X. (2018). A Study on the Effects to Students' STEM Academic Achievement with Chinese Parents' Participative Styles in School Education. Educational Sciences: Theory and Practice, 19(1), 41-54. 
Anggraini, P., \& Kusniarti, T. (2016). The Implementation of character education model based on empowerment theatre for primary school students. Journal of Education and Practice, 7(1), 26-29.

*Anwar, S. (2014). Pendidikan karakter di Madrasah Ibtidaiyah Modern Sahid [Character education at Madrasah Ibtidaiyah Modern Sahid], Bogor, Jawa Barat. Edukasi, 12(3), 323-337.

Apino, E., \& Retnawati, H. (2017). Developing instructional design to improve mathematical higher order thinking skills of students. Journal of Physics: Conference Series, 812, 1-7.

Budiarta. L. G. R, Artini. L. P., Seken. I. K., \& Santosa, M. H. (2018). How consistent is teachers' planning, implementation, and assessment in character education? SHS Web of Conferences, 42, 1-6.

Castro, M., Expósito-Casas,E., López-Martín, E., Lizasoain, L., Navarro-Asencio, E.\& Gaviria, J. L. (2015). Parental involvement on student academic achievement: A meta-analysis. Educational Research Review, 14(1), 33-46.

Chou, M.-J., Yang, C.-H., \& Huang, P.-C. (2014). The beauty of character education on preschool children's parent-child relationship. Procedia-Social and Behavioral Sciences, 143, 527-533.

Çubukçu, Z. (2012). The effect of hidden curriculum on character education process of primary school students. Educational Sciences: Theory and Practice, 12(2), 1526-1534.

*Darmansyah. (2014). Teknik penilaian sikap spritual dan sosial dalam pendidikan karakter di sekolah dasar 08 Surau Gadang Nanggalo [Techniques for assessing spiritual and social attitudes in character education in elementary school number 08 Surau Gadang Nanggalo\}. Jurnal Al-Ta'lim, 21(1), 10-17.

*Darmayanti, S.E., \& Wibowo, U.B. (2014). Evaluasi program pendidikan karakter di sekolah dasar kabupaten Kulon Progo [Evaluation of the character education program at the Kulon Progo district primary school], Jurnal Prima Edukasi, 2(2), 223-234.

Demirel, M., Özmat, D., \& Elgün, I. O. (2016). Primary school teachers' perceptions about character education. Educational research and reviews. 11(17), 1622-1633.

Dodds, D. M. (2016). The effects of character education on social-emotional behavioral. Master of Arts in Education Action Research Paper. Paper 137.

Erdener, M. A. (2016). Principals and Teachers Practices about Parent Involvement in Schooling. Universal Journal of Educational Research, 4(12A), 151-159.

Erdener, M. A., \& Knoeppel, R. C. (2018). Parents' Perceptions of Their Involvement in Schooling. International Journal of Research in Education and Science (IJRES), 4(1), 1-13.

*Fahmi, M. N., \& Susanto, S. (2018). Implementasi pembiasaan pendidikan islam dalam membentuk karakter religius siswa sekolah dasar [The implementation of the habituation of Islamic education in shaping the religious character of elementary school students\}. Pedagogia : Jurnal Pendidikan, 7(2), 85-89.

Fahmy, R., Bachtiar, N., Rahim, R., \& Malik, M. (2015). Measuring student perceptions to personal characters building in education: An Indonesian case in implementing new curriculum in high school. Procedia-Social and Behavioral Sciences, 211, 851-858.

Ferdiawan, E., \& Putra, W. E. (2013). Esq education for children character building based on phylosophy of Javanese in Indonesia. Procedia-Social and Behavioral Sciences, 106, 1096-1102.

Flores, R. Q., Morgan, P., Rivera, L., \& Clark, C. (2019). Latinx Family Engagement in Schools and Surrounding Communities: Assessing the Impact of Parent (and Other Family Member) Development on Improving Student Educational Outcomes at GeneWard Elementary School. Education sciences, 9, 149.

Greenstein, L. (2012). Assesing 21 st Century Skill, A Guide to Evaluating Mastery and Authentic Learning. USA: Corwin A Sage Company.

Grissom, J. A., Kalogrides, D. \& Loeb, S. (2015). The micropolitics of educational inequality: The case of teacher-student assignments. Peabody Journal of Education, 90(5), 601-614.

*Hamzah, A. (2016). Profil Pembelajaran Karakter di Sekolah Dasar [Character Learning Profile in Elementary School]. JINOTEP, 3(1), 31-50.

*Hidayati, M., Tohiroh, L., \& Istyarini. (2017). Evaluasi Program Pendidikan Akhlak di Full Day School Sekolah Dasar Islam Terpadu [Evaluation of Moral Education Program at Full Day School of Integrated Islamic Elementary School]. Indonesian Journal of Curriculum and Educational Technology Studies, 5(10), 10-21.

Istiningsih. (2016). Character Education of the Most Developed Countries in ASEAN. Journal of Education and e-Learning Research, 3(1), 32-37.

Jailani, J., Sugiman, S., \& Apino, E. (2017). Implementing the problem-based learning in order to improve the students' HOTS and characters. Jurnal Riset Pendidikan Matematika, 4 (2), 247-259.

Khoury, R. (2017). Character Education as a Bridge from Elementary to Middle School: A Case Study of Effective Practices and Processes. International Journal of Teacher Leadership. 8(2), 49-67. 
Koagouw, M. O. (2019, December 31). Sepanjang 2019, 153 Anak jadi Korban Fisik dan Bullying. Rri.co.id.

*Latip, A.E. (2013). Pembelajaran berbasis karakter di Madrasah Ibtidaiyah [Character-based learning at Madrasah Ibtidaiyah]. Jurnal Pendidikan Islam, 28(1), 40-58.

Malinda, H., Mwania, J., \& Maithya, R. (2017). Strategies for fostering character development education by teachers in Kenyan schools. African Educational Research Journal, 5(1), 64-74.

Marini, A. (2017). Character Building through Teaching Learning Process: Lesson in Indonesia. International Journal of Sciences and Research, 73(5), 177-182.

Mislia, Mahmud, A., \& Manda, D. (2016). The implementation of character education through scout activities. International Education Studies, 9(6), 130-138.

Moher, D., Liberati, A., Tetzlaff, J., \& Altman, D. G. (2009). Preferred reporting items for systematic reviews and meta-analyses: The PRISMA statement. Annals of Internal Medicine, 151(4), 264-269.

*Morelent, Y \& Syofiani. (2015). Pengaruh penerapan kurikulum 2013 terhadap pembentukan karakter siswa Sekolah Dasar Negeri 05 Percobaan Pintu Kabun Bukittinggi [The effect of the 2013 curriculum implementation on the character building of the students of the 05 Trial of Pintu Pintu Kabun Bukittinggi]. Jurnal Penelitian Bahasa dan Sastra Indonesia, 1(2), 141-152.

*Narut, Y.F., \& Nardi, M. (2019). Analisis sikap peduli lingkungan pada siswa kelas VI Sekolah Dasar di Kota Ruteng [Analysis of the environmental care attitude of grade VI Elementary School students in Ruteng City]. Scholaria: Jurnal Pendidikan dan Kebudayaan, 9(3), 259-266.

Nastiti, T. A. (2015). Implementasi Program Full Day School Dalam Pembentukan Karakter Anak Di SD Islam Terpadu Taruna Teladan Delanggu Tahun 2015/2016 [Implementation of the Full Day School Program in Building Children's Character In Integrated Islamic Elementary School, Delanggu Teladan Taruna 2015/2016]. SOSIALITAS; Jurnal Ilmiah Pend. Sos Ant, 5(2), 1-8.

*Nitte, Y.M., \& Bulu, V.R. (2020). Pemetaan implementasi pendidikan karakter di Sekolah Dasar se-Kota Kupang [Mapping the implementation of character education in elementary schools in Kupang City\}. Jurnal Kependidikan: Jurnal Hasil Penelitian dan Kajian Kepustakaan di Bidang Pendidikan, Pengajaran dan Pembelajaran, 6(1), 38-47.

Nurhasanah, N., \& Nida, Q. (2016). Character building of students by guidance and counseling teachers through guidance and counseling services. Jurnal Ilmiah Peuradeun, 4 (1), 65-76.

Pane, M, M., \& Patriana, R. (2016). The significance of environmental contents in character education for quality of life. Procedia-Social and Behavioral Sciences, 222, 244-252.

Pang, N. S., \& Miao, Z. (2017). The Supports of Teacher Leadership in Shanghai Education Success. Bulgarian Comparative Education Society, 15, 93-100.

*Parida, L., Sirhi, S., \& Dike, D. (2019). Pola kepemimpinan kepala sekolah dalam penguatan karakter di Sekolah Dasar Kota Sintang-Kalimantan Barat [The leadership pattern of the principal in strengthening character in the Elementary Schools of Sintang City, West Kalimantan\}. JPPD, 6(2), $145-164$.

Pattarro, C. (2016). Character education: Themes and researches. An academic literature review. Italian Journal of Sociology of Education, 8(1), 6-30.

Presidential Regulation Number 87 Year 2017 concerning Strengthening Character Education.

Putra, I. P. (2020, April 7). Kemampuan Literasi Siswa Indonesia Mandek Selama 18 Tahun. Medcom.id. Retrieved from https://www.medcom.id/pendidikan/news-pendidikan/lKYx6Ljk-kemampuanliterasi-indonesia-mandek-selama-18-tahun

Retnawati, H., Djidu, H., Kartianom, K., Apino, E., \& Anazifa, R. D. (2018). Teachers knowledge about higher-order thinking skills and its learning strategy. Problems of Education in the 21 ${ }^{\text {st }}$ Century, 76(2), 215-230.

Rokhman, F., Hum, M., Syaifudin, A., \& Yuliati. (2014). Character education for golden generation 2045 (national character building for Indonesian golden years). Social and Behavioral Sciences, 141, $1161-1165$.

*Sadia, W. Arnyana, I.B.P., \& Muderawan.W. (2013). Model pendidikan karakter terintegrasi pembelajaran sains [The integrated character education model of science learning]. Jurnal Pendidikan Indonesia, 2(2), 209-220.

Sahin, U. (2019). Parents' Participation Types in School Education. International Journal of Educational Methodology, 5(3), 315-324.

Saidek, A. R., Islami, R., \& Abdoludin. (2016). Character Issues: Reality Character Problems and Solutions through Education in Indonesia. Journal of Education and Practice, 7(17), 158-165.

*Salam, M. (2017). Peran kepemimpinan kepala sekolah dalam implementasi pendidikan karakter Di Sekolah Dasar [The role of principal leadership in the implementation of character education in elementary schools]. Jurnal Gentala Pendidikan Dasar, 2(2), 329-345. 
*Siagian, N. (2015). Implementasi pendidikan karakter: Kasus di Sekolah Dasar Islam Terpadu Nurul Ilmi Kota Jambi [Implementation of character education: The case at the Nurul Ilmi Integrated Islamic Primary School, Jambi City]. PENAMAS, 28(2), 243 - 258.

*Sujatmiko, I.N., Arifin, I., \& Sunandar, A. (2019). Penguatan pendidikan karakter di SD [Strengthening character education in elementary schools]. Jurnal Pendidikan: Teori, Penelitian, dan Pengembangan, 4(8), 1113-1119.

Sultoni, A. (2016). Pendidikan karakter dan kemajuan negara: Studi perbandingan lintas negara [Character education and state progress: Comparative study across countries]. Journal of Islamic Education Studies, 1(1), 184-207.

*Suprio, Hanurawan \& Sutarno. 2020. Keterampilan sosial siswa Sekolah Dasar dalam penguatan pendidikan karakter berbasis budaya sekolah [Elementary school students' social skills in strengthening character education based on school culture]. Jurnal Pendidikan: Teori, Penelitian, dan Pengembangan, 5(1), 121-126.

Temiz, N. (2016). Example of Character Education Course Design in the Light of Experienced Centred Design for Higher Education. Journal of Education and Practice, 7(36), 144-155.

Temiz, N. (2019). A lesson plan model for character education in primary education. Educational Research and Reviews, 14(4), 130-139.

Toren, N. K. (2013). Multiple dimensions of parental involvement and its links to young adolescent selfevaluation and academic achievement. Psychology in the Schools, 50(6), 634-649.

Turan, F., \& Ulutas, I. (2016). Using Storybooks as a Character Education Tools. Journal of Education and Practice, 7(15), 169-176.

Ülger, M., Yiğittir, S., \& Ercan, O. (2014). Seondary school teachers' beliefs on character education competency. Procedia-Social and Behavioral Sciences, 131, 442-449.

Wei, W., Wu, Y.F., Lv, B., Zhou, H., Han, X.H., Liu, Z. M., \& Luo, L. (2016). The Relationship Between Parental Involvement and Elementary Students' Academic Achievement in China: One-Only Children vs. Children with Siblings. Journal of Comparative Family Studies, 47(4), 483-500.

*Wibowo, A.M. (2014). Pendidikan karakter melalui pendidikan agama islam di Sekolah Dasar Islam Terpadu di Kota Yogyakarta [Character education through Islamic religious education at the Integrated Islamic Elementary School in Yogyakarta City]. Edukasi, 12(3), 311-322.

*Wijanarti, W., Degeng, I.N.S \& Untari, S. (2019). Problematika pengintegrasian penguatan pendidikan karakter pada pembelajaran tematik [The problem of integrating the strengthening of character education in thematic learning]. Jurnal Pendidikan: Teori, Penelitian, dan Pengembangan, 4(3), 393-398.

*Yalida, A. (2019). Pendidikan Karakter yang Berbasis pada Nilai-nilai Pancasila Kelas IV SDN No. 88 Kota Tengah Kota Gorontalo [Character Education Based on Pancasila Values Class IV SDN No. 88 Kota Tengah Kota Gorontalo]. Jurnal Pendidikan Islam Al-Ilmi, 2(1), 23-32.

Yulianti, K., Denessen, E., \& Droop, M. (2019). Indonesian Parents' Involvement in Their Children's Education: A Study in Elementary Schools in Urban and Rural Java, Indonesia. School Community Journal, 29 (1), 253-278.

Zuhri. S. (2014). Implementasi pendidikan karakter di SD Islamal- Alazhar Solo Baru [Implementation of character education at SD Islamal - Alazhar Solo Baru]. Suhuf. 26(2), 131-147.

Zurqoni, Retnawati, H., Apino, E., \& Anazifa, R. D. (2018). Impact of character education implementation: A goal-free evaluation. Challenges Of Education In The 21st Century, 76(6), 881-899. 